\title{
SYSTEMIC LUPUS ERYTHEMATOSUS COMPLICATED WITH HYPOPLASTIC MARROW AND HAEMOPHAGOCYTOSIS: A CASE REPORT
}

R. K. Banashree Devi1, Ksh. Achouba Singh², Nisa Kaiho³, Tonny Kh ${ }^{4}$

\section{HOW TO CITE THIS ARTICLE:}

R. K. Banashree Devi, Ksh. Achouba Singh, Nisa Kaiho, Tonny Kh. "Systemic Lupus Erythematosus Complicated with Hypoplastic Marrow and Haemophagocytosis: A Case Report". Journal of Evolution of Medical and Dental Sciences 2015; Vol. 4, Issue 39, May 14; Page: 6886-6890, DOI: 10.14260/jemds/2015/998

ABSTRACT: Association of systemic lupus erythromatosus with hemophagocytic lymphohistiocytosis (HLH) has been reported by many authors ${ }^{1,2,3,4}$ however association of systemic lupus erythromatosus with hemophagocytic lymphohistiocytosis and hypoplastic bone marrow is quite rare. Here we are reporting a case of HLH developing in a known case of SLE presenting with hypoplastic bone marrow in a 45 years old female, on low dose steroid therapy who presented with febrile pancytopenia, hepatosplenomegaly, hyperferritinemia with evidence of bone marrow hypoplasia and haemophagocytosis.

KEYWORDS: Systemic lupus erythematosus, hypoplastic marrow, haemophagocytosis.

INTRODUCTION: Hemophagocytic lymphohistiocytosis (HLH) is a rare disorder of the immune system. In Sweden, the incidence was estimated at 1.2 per million per year5.It usually affects young children but may occur at any age. HLH is often referred to as either the primary form which is hereditary or the secondary form, associated with infections (may be viral), autoimmune diseases, and malignancies. The primary form, also known as familial hemophagocytic lymphohistiocytosis (FHLH) is inherited either as autosomal recessive or X linked forms. Five genes have been identified which correspond with five subtypes of autosomal recessive HLH. The genes encodes the protein normally involved in killing or eliminating abnormal immune cells or proteins which facilitate the delivery of perforin to the cells which are to be killed.

Primary form is usually seen in young children. Secondary HLH is often diagnosed in older patients with no positive family history of this disease. It may be associated with viral infections such as Epstein-Barr, cytomegalovirus (CMV) or herpes virus, autoimmune disorders and cancers. In both forms of the disease there is excessive activation of the macrophages and histiocytes producing haemophagocytosis in bone marrow and reticuloendothelial system. Patients usually present with fever (91\%), hepatomegaly (90\%), splenomegaly (84\%), neurologic signs (47\%), rash (43\%) and lymphadenopathy $(42 \%){ }^{6}$

Our case is a 45 years old female, known case of systemic lupus erythromatosus on corticosteroid therapy (Prednisolone 5mg per day) presented with complaints of prolonged fever, generalized weakness, malaise and rapidly increasing skin rashes for the past one month. Two weeks prior to admission, the dose of steroid was escalated to $20 \mathrm{mg}$ three times daily on suspicion of progression of the basic disease. On examination the patient was febrile (temp. $-103^{\circ} \mathrm{F}$ ), anaemic, icteric mildly with mild hepatosplenomegaly and psoriasiform rashes all over the body. Other systemic examinations were unremarkable. The following tables show the laboratory findings of the patient. 


\section{CASE REPORT}

\begin{tabular}{|c|c|c|}
\hline Parameters & Initial & Repeat \\
\hline Haemoglobin $(\mathrm{Hb})$ & $8.5 \mathrm{gm} / \mathrm{dl}$ & $7 \mathrm{gm} / \mathrm{dl}$ \\
\hline Total erythrocyte count & 3.3 million/cu mm & \\
\hline Packed cell volume (PCV) & $25.8 \%$ & \\
\hline Mean corpuscular volume (MCV) & $78 f l$ & \\
\hline Mean corpuscular $\mathrm{Hb}(\mathrm{MCH})$ & $25.7 \mathrm{pg}$ & \\
\hline $\begin{array}{l}\text { Mean corpuscular Hb Conc } \\
\text { (MCHC) }\end{array}$ & $32.9 \mathrm{gm} / \mathrm{dl}$ & \\
\hline RDW & $16.6 \%$ & \\
\hline Total leucocyte count (TLC) & $3120 / \mathrm{cu} \mathrm{mm}$ & $2580 / \mathrm{cu} \mathrm{mm}$ \\
\hline Total lymphocyte count & $610 / \mathrm{cu} \mathrm{mm}$ & $390 / \mathrm{cu} \mathrm{mm}$ \\
\hline Total granulocyte count & 2300/cu mm & $1600 / \mathrm{cu} \mathrm{mm}$ \\
\hline Differential count (DLC) & P 74, L20, M5, E1 & P 67, L 16, M 1, E 6 \\
\hline Platelet count & $1.1 \mathrm{lac} / \mathrm{cu} \mathrm{mm}$ & $90000 / \mathrm{cu} \mathrm{mm}$ \\
\hline Reticulocyte count & $0.3 \%$ & \\
\hline ESR & $46 \mathrm{~mm}$ in first hour & $136 \mathrm{~mm}$ in first hour \\
\hline Peripheral smear picture & $\begin{array}{l}\text { Microcytic hypochromic red } \\
\text { cells with thrombocytopenia } \\
\text { with normal morphology. No } \\
\text { haemoparasite and atypical } \\
\text { cells seen }\end{array}$ & $\begin{array}{l}\text { Microcytic } \\
\text { hypochromic red cell } \\
\text { with moderate } \\
\text { anisocytosis }\end{array}$ \\
\hline
\end{tabular}

\begin{tabular}{|c|c|}
\hline Parameters & Values \\
\hline Total bilirubin & $1.2 \mathrm{mg}$ \\
\hline SGOT & $80 \mathrm{U} / \mathrm{L}$ \\
\hline SGPT & $76 \mathrm{U} / \mathrm{L}$ \\
\hline Gamma glutamyl transferase & $52 \mathrm{U} / \mathrm{L}$ \\
\hline Alkaline phosphatase & $85 \mathrm{U} / \mathrm{L}$ \\
\hline Total protein & $6.8 \mathrm{gm} \%$ \\
\hline Albumin & $3.5 \mathrm{gm} \%$ \\
\hline Globulin & $3.5 \mathrm{gm} \%$ \\
\hline A:G ratio & $1: 1$. \\
\hline Urea & $27 \mathrm{mg} \%$ \\
\hline Creatinine & $0.9 \mathrm{mg} \%$ \\
\hline Sodium & $129 \mathrm{meq} / \mathrm{L}$ \\
\hline Potassium & $4.1 \mathrm{meq} / \mathrm{L}$ \\
\hline
\end{tabular}

Table 2: Liver and Renal Function Tests 


\section{CASE REPORT}

\begin{tabular}{|c|c|c|}
\hline Repeated Urine Culture & Sterile & \\
\hline Blood culture & Sterile & \\
\hline Quantitative buffy coat & Negative for malaria parasite & \\
\hline ANA & 1.2 (positive) & speckled \\
\hline Anti-ds DNA & 34 & \\
\hline Enterocheck & negative & \\
\hline Mantoux test & Normal & \\
\hline CXR PA View & Normal study, no vegetations was found & \\
\hline Echocardiography & Normal & \\
\hline Hb electrophoresis & 564ug/dl & \\
\hline Serum ferritin & mild hepatosplenomegaly & \\
\hline Ultrasound whole abdomen & Table 3: Other Laboratory tests & \\
\hline \multicolumn{2}{|c}{}
\end{tabular}

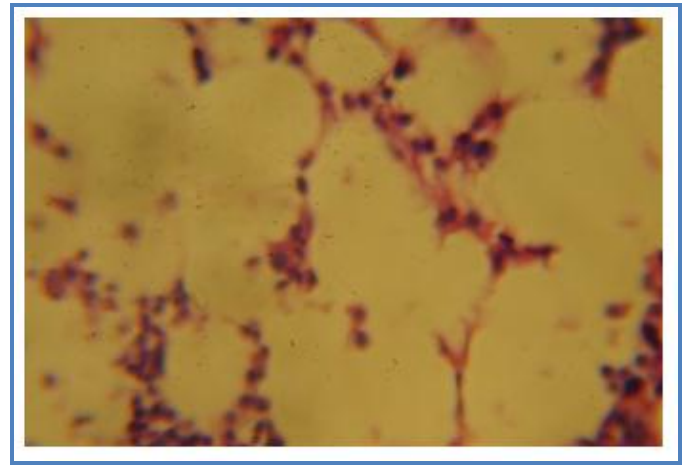

Fig. 1: Histopathological section of Bone marrow Biopsy showing hypocellular marrow. (Haematoxylin and Eosin stain, $400 \mathrm{x}$ magnifications)

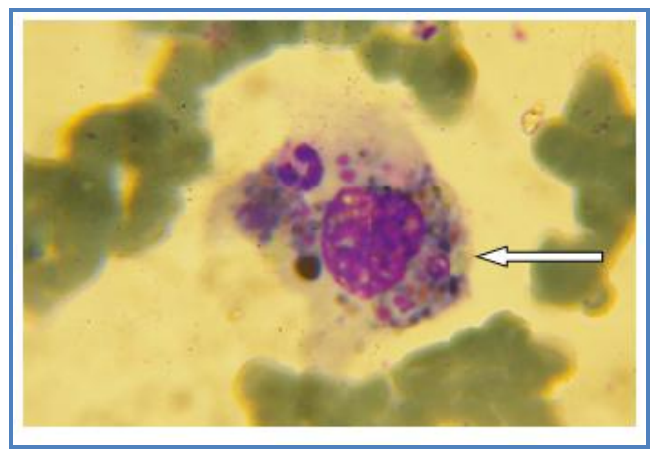

Fig. 2: Photomicrograph of bone marrow aspirate showing a macrophage with degenerated haemic cells in the cytoplasm (Leshmann Stain, 1000x magnification)

Patient continued to be febrile. Repeat blood \& urine cultures showed no growth of organism (Both aerobic and anaerobic). A complete viral screen (EBV, Herpes virus, and parvo virus) was done 


\section{CASE REPORT}

and showed no sign of recent infection. Patient was subjected to bone marrow examination as part of investigation for pyrexia of unknown origin. Under aseptic conditions bone marrow biopsy \& aspiration were performed on the right posterior iliac crest. Consistency was normal, Cellularity was reduced (Around 15\%) with reduction of all cell lineages (Fig. 1). Erythropoiesis was predominantly normoblastic. Differential leucocyte count was within normal range.

Myeloid: Erythroid ratio was 3.5:1. Reduction of the number of megakaryocytes with normal morphology was seen. Bone marrow iron store was increased (Grade 4). Most striking feature was the presence of many macrophages engulfing haemic cells including leukocytes \& red cells (Fig. 2). A diagnosis of Hypoplastic anaemia with haemophagocytosis in a patient of SLE was finally considered. However, the exact cause for prolonged intermittent fever was not found. High dose corticosteroid in the form of Methylprednisolone intravenous was given. Fever gradually subsided and the general condition of the patient improved subsequently.

DISCUSSION: HPS is a rare entity characterised by proliferation of nonneoplastic cells of histiocytic lineage along with evidence of haemophagocytosis. The course of the disease is usually aggressive and potentially fatal. It may be associated with the marrow hypoplasia seen may be due to therapy with Cyclophosphamide. Marrow toxicity is the most important toxic effect, depends on the total cumulative dose $^{7}$ (Bruce A. Chabner at el) or may be associated with autoimmune disorder like SLE ${ }^{8}$ (Aplastic anaemia: acquired and inherited, George B. Segel and et al).

In our case, the levels of serum auto antibodies were just marginally raised; however the signs and symptoms could not be due to aggravating primary disease. Moreover the findings in our case satisfied the diagnostic criteria laid by Histiocyte Society (Histiocyte Society treatment protocol HLH-2004). ${ }^{9}$ Increasing neutropenia with high ferritin level was noted. Findings in our case satisfied criteria for diagnosis of LHL according to Histiocyte society treatment protocol, HLH 2004.

\section{REFERENCES:}

1. Egües Dubuc CA et al, Hemophagocytic Syndrome as the Initial Manifestation of Systemic Lupus Erythematosus - Case Report. Reumatol Clin. 2014; 10(5):321-324.

2. Swati Kalra et al. Hemophagocytic Lymphohistiocytosis as Presenting Feature of Lupus. Indian Paediatrics. December 16, 2012; Vol 49: 993.

3. Maciej Machaczka and et al. Autoimmune-Associated Hemophagocytic Syndrome/Macrophage Activation Syndrome. www.intechopen.com.

4. Po-Chung Cheng1, Yun-Chung Cheng. Systemic lupus erythematosus associated hemophagocytic lymphohistiocytosis: A case report and literature review. American Journal of Internal Medicine. Vol. 2, No. 3, 2014, pp. 49-53.

5. Henter JI and et al. Incidence in Sweden and clinical features of familial hemophagocytic lymphohistiocytosis. Acta Paediatr Scand, 80:428, 1991.

6. Janka GE: familial hemophagocytic lymphohistiocytosis. Eur J Pediatr 140:221, 1983.

7. Bruce A. Chabner at el. Pharmacology \&toxicity of antineoplastic drugs. Williams haematology, 8th Edition: 283-312.

8. George B. Segel and et al. Aplastic anaemia: acquired and inherited. Williams haematology, 8th Edition: 463-483. 


\section{CASE REPORT}

9. Kenneth L. et al. Inflammatory and malignant histiocytosis. Williams haematology, $8^{\text {th }}$ Edition: 1047-1064.

\section{AUTHORS: \\ 1. R. K. Banashree Devi \\ 2. Ksh. Achouba Singh \\ 3. Nisa Kaiho \\ 4. Tonny Kh}

\section{PARTICULARS OF CONTRIBUTORS:}

1. Pathologist, JNIMS, Imphal, Manipur.

2. Endocrinologist, JNIMS, Imphal, Manipur.

3. Senior Resident, Department of Pathology, JNIMS, Imphal, Manipur.

\section{FINANCIAL OR OTHER} COMPETING INTERESTS: None
4. Senior Resident, Department of Pathology, JNIMS, Imphal, Manipur.

NAME ADDRESS EMAIL ID OF THE CORRESPONDING AUTHOR:

Dr. R. K. Banashree Devi, MD,

Uripok Bachaspati Maning Leikai, Imphal-795001, Manipur.

E-mail: bibiachouba@yahoo.com

Date of Submission: 21/04/2015.

Date of Peer Review: 22/04/2015.

Date of Acceptance: 06/05/2015.

Date of Publishing: 14/05/2015. 